\title{
A FLOW MODEL AND A TIME SCALE FOR THE ICE CORE FROM CAMP CENTURY, GREENLAND
}

\author{
By W. Dansgaard and S. J. Johnsen \\ (Fysisk Laboratorium II, H.C. Orsted Institutet, Københavns Universitet, København, \\ Denmark)
}

\begin{abstract}
A flow model is described for the Camp Century area in Greenland. The horizontal velocity profile along the core is assumed to be uniform from the surface down to $y=400 \mathrm{~m}$ above the bottom. Below this level, the horizontal velocity $v_{x}$ is assumed to decrease proportionally to $y$. Furthermore, at a given $y, v_{x}$ is assumed to be proportional to the distance $x$ from the ice divide. The resulting vertical strainrate under steady-state conditions gives the age of the ice as a function of $y$. The flow model has explained the measured temperature profile, and the time scale has been verified by comparison between observed stable isotope variations and past climatic changes (at least 70 ooo years back in time) estimated by other methods.

RÉsumé. Un modèle d'écoulement et une échelle de lemps pour la carotte de glace du Camp Century, Groenland. Les auteurs décrivent un modèle d'écoulement de la glace pour la zone du Camp Century au Groenland. Le profil horizontal des vitesses tout au mond de la carotte de glace est supposé être uniforme de la surface jusqu'à une profondeur de $y=400 \mathrm{~m}$ au-dessus de socle rocheux. En-dessous de ce niveau, la vitesse horizontale $v_{x}$ est supposée décroître proportionnellement à $y$. De plus, à une profondeur $y$ donnée. $v_{x}$ est supposée être proportionnelle à la distance $x$ de la ligne de séparation des glaces. La vitesse de déformation verticale qui en résulte sous des conditions stationnaires donne l'âge de la glace en fonction de $y$. Le modèle d'écoulement a expliqué le profil mesuré des températures et l'échelle des temps a été vérifiée par comparaison des variations observées des concentrations d'isotope stable et les changements climatiques passées (jusqu'à 70 ooo ans en arrière) estimés par d'autres méthodes.

Zusammenfassung. Ein Fliessmodell und eine Zeilskala für den Bohrkern von Camp Century, Grönland. Für das Gebiet von Camp Century in Grönland wird ein Fliessmodell beschrieben. Das Horizontalgeschwindigkeitsprofil entlang des Kerns wird von der Oberfläche bis zu $y=400 \mathrm{~m}$ über dem Boden als gleichförmig angenommen. Darunter wird eine Abnahme der Horizontalgeschwindigkeit $v_{x}$ proportional zu $y$ vorausgesetzt. Weiterhin wird unterstellt, dass sich für ein gegebenes $y v_{x}$ proportional zur Entfernung $x$ von der Eisscheide verhält. Die resultierende vertikale Verformungsgeschwindigkeit unter stetigen Bedingungen ergibt das Alter des Eises als eine Funktion von $y$. Das Fliessmodell erklärt das gemessene Temperaturprofil; die Zeitskala wird durch einen Vergleich zwischen beobachteten Variationen stabiler Isotope und früheren Klimaschwankungen (zumindest in den letzten 70 ooo Jahren), die mit anderen Methoden abgeschätzt werden, bestätigt.
\end{abstract}

\section{INTRODUCTION}

Ice cores contain information on climatic and geochemical conditions of the past, because the isotopic and chemical composition of falling snow remains unchanged in glacier ice for long periods of time. However, the value of isotopic and chemical analysis is, of course, closely related to a knowledge of the age of the ice in question. This emphasizes the necessity for establishing a time versus depth relation.

Macroscopic stratigraphic studies have been used by many investigators on the upper strata of ice which are no more than a few hundred years old. However, the technique based on seasonal variation in light transmissivity (Langway, 1967) might be used for ice several thousand years old (Johnsen and others, unpublished).

Another possible way of establishing a time scale along an ice core would seem to be the measurement of seasonal oscillations in the isotopic composition of the ice (Epstein and Sharp, r959) and counting isotopic maxima from the surface. However, various processes tend to diminish the isotopic gradients in snow and ice. For example, molecular diffusion in the solid ice, accelerated by the thinning of the layers, gradually obliterates the stable isotope oscillations that remain after firnification (Johnsen and Dansgaard, unpublished).

Four radioactive isotopes have been used for dating ice. Tritium (Aegerter and others, ${ }_{1969)}$ and ${ }^{210} \mathrm{~Pb}$ (Goldberg, I963; Crozaz and others, I964; Crozaz and Langway, I966) reach only 100 years back in time. The other two, ${ }^{32} \mathrm{Si}$ (Dansgaard and others, 1966 ) and ${ }^{14} \mathrm{C}$. (Scholander and others, I962), may be detected in 3000 and $20000-30$ ooo year-old ice, respectively, but both of these techniques require several tons of ice. The technique for sampling ${ }^{14} \mathrm{C}$ from ice in situ, developed by Oeschger and others (1967), might in the future be perfected to be applied to deep bore holes. 
But at present a time scale for the Camp Century core must be based on calculations on a chosen flow model.

The Nye Model

Most of the previously evaluated flow models imply a uniform vertical strain-rate along any vertical line in an ice cap (Nye, 1951, 1957, 1959). Furthermore, assuming that the horizontal velocity components are parallel and there is negligible melting at the bottom, Nye (1963) expressed the ratio between the reduced and initial thicknesses, $\lambda$ and $\lambda_{H}$, of an annual layer (e.g. in $\mathrm{cm}$ of ice) by

$$
\frac{\lambda}{\lambda_{H}}=\frac{y}{H}
$$

$y$ and $H$ being its present and initial distance from the bed.

With this model, we get the change of $\lambda$ per unit of time

$$
\frac{\mathrm{d} \lambda}{\mathrm{d} t}=\frac{\lambda_{H}}{H} \frac{\mathrm{d} y}{\mathrm{~d} t}=-\frac{\lambda_{H} \lambda}{H_{\tau}},
$$

$\tau$ being I year. Integration gives $\lambda$ as a function of time

$$
\lambda=\lambda_{H} \exp \left(-\frac{\lambda_{H} t}{H \tau}\right)
$$

and from Equation (I) we get the depth of a layer age $t$ formed at a height $H$ above the bottom

$$
y=\frac{H \lambda}{\lambda_{H}}=H \exp \left(-\frac{\lambda_{H} t}{H \tau}\right) .
$$

Hence, the age of a layer $(H-y)$ below surface (cf. Haefeli, I96I)

$$
t=-\frac{H \tau}{\lambda_{H}} \ln \frac{y}{H}
$$

Figure I shows $\lambda$ as a function of time (Equation (2)) for $H=\mathrm{I} 400 \mathrm{~m}$ and $\lambda_{H}=0.2$ and $0.35 \mathrm{~m}$. Paradoxically, the highest value of $\lambda_{H}$ corresponds to the thinnest layers after 5000 years. The explanation is that, for a given value of $H$, the horizontal movement and, therefore, the vertical strain-rate will be the faster the higher the rate of accumulation.

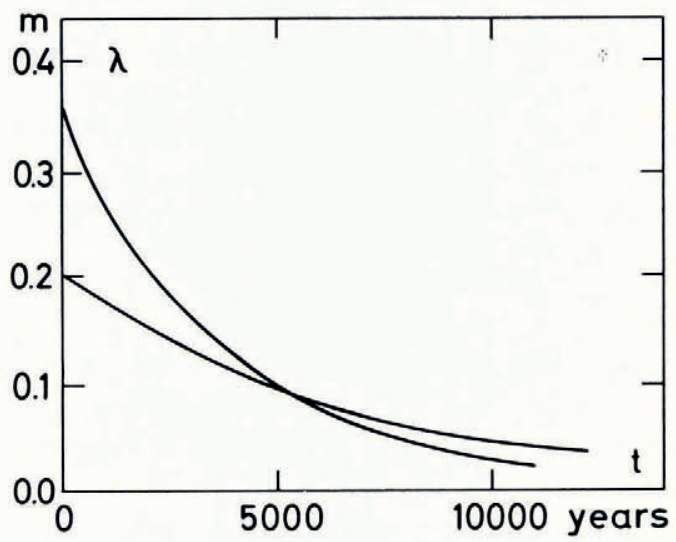

Fig. I. Thickness $\lambda$ of an annual layer as a function of age $t$, according to the $\mathcal{N} y e$ flow model. Initial thicknesses 0.35 and $0.20 \mathrm{~m}$. Thickness of the ice sheet $H=1400 \mathrm{~m}$. 
The Nye model describes the flow conditions at the bedrock by sliding and/or by rapid shear strain-rates being concentrated in a thin bottom layer (Nye, i 963 ). However, at Camp Century the sliding is probably negligible, because the temperature at the bottom is as low as $-\mathrm{I}_{3}{ }^{\circ} \mathrm{C}$ (Hansen and Langway, I 966 ). Furthermore, the idea of relative motion being essentially concentrated in a thin bottom layer was advanced in view of the fact that the flow law of ice depends critically upon the temperature, at the same time as the temperature gradient at the bottom was assumed to be as high as $10^{\circ} \mathrm{C} / 100 \mathrm{~m}$ (Nye, 1959). However, at Camp Century the temperature gradient was later measured to be only $1.8^{\circ} \mathrm{C} / \mathrm{I}$ oo $\mathrm{m}$ (Hansen and Langway, I966). Consequently, Nye's flow model is not necessarily applicable in the case of the Camp Century area.

\section{Non-uniform Vertical Strain-rate Model}

Another approach would be to assume, like Nye ( 1963 ), that the horizontal velocity profile along a vertical line in the distance $x$ from the ice divide may be written as

$$
v_{x}(y)=k \cdot f(y) \cdot x
$$

and also to calculate $v_{x}(y)$ by integrating Glen's law (Haefeli, I96r)

$$
v_{x}(y)=\int_{0}^{y} k^{\prime} \sigma^{n} \mathrm{~d} y,
$$

$\sigma$ being the shear stress, $k^{\prime}$ and $n$ being constants that depend on the temperature and therefore on $y$. This integration is justified only if the longitudinal strain-rate is small compared with the shear strain-rate at any $y$, which is only the case in the lower part of the ice sheet. Nevertheless, we consider Weertman's (1968) calculation of Equation (5), shown as the full curve in Figure 2, as an improvement compared with calculations based on a uniform vertical strain-rate, because Weertman's procedure accounts for the important fact, that $v_{x}(y)=0$ for $y=0$. In this work, we use the simple approximation shown as the dashed curve in Figure 2, i.e. $v_{x}$ proportional to $y$ from $y=0$ to $y=h$, and $v_{x}$ independent of $y$ from $y=h$ to $y=H$ or, in other words

$$
\begin{array}{ll}
f(y)=y / h, & 0 \leqslant y \leqslant h, \\
f(y)=\mathrm{I} & h \leqslant y \leqslant H .
\end{array}
$$

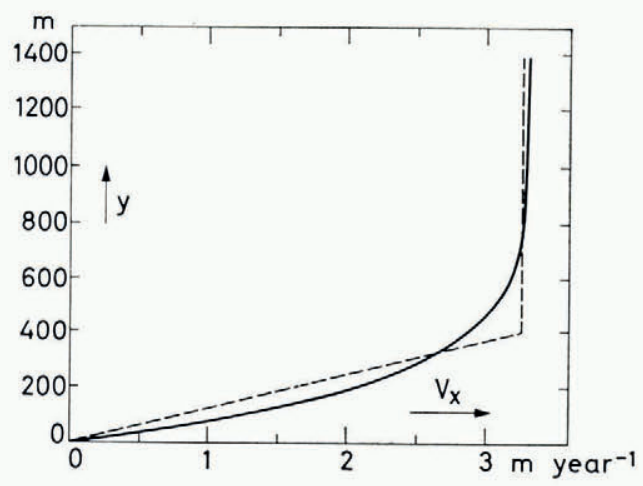

Fig. 2. Full curve: horizontal velocity profile calculated by integration of Glen's law, assuming $v_{x}(o)=o$ and $v_{x}(H)=3 \cdot 3$ $m$ year $^{-1}$ (from Weertman, 1968$)$. Dashed curve: adopted approximation. 
The incompressibility of the ice is expressed by

$$
\frac{\partial v_{y}}{\partial y}+\frac{\partial v_{x}}{\partial x}=\mathrm{o}
$$

and the vertical velocity component is calculated as

$$
\begin{gathered}
\frac{\partial v_{y}}{\partial y}=-\frac{\partial v_{x}}{\partial x}=-k f(y), \\
v_{y}=-k \int_{0}^{y} f(y) \mathrm{d} y
\end{gathered}
$$

and, according to Equation (6)

$$
v_{y}= \begin{cases}-k y^{2} / 2 h, & 0 \leqslant y \leqslant h \\ -\frac{k}{2}(2 y-h), & h \leqslant y \leqslant H .\end{cases}
$$

For $y=h$ :

$$
v_{h}=-\lambda_{h} / \tau=-\frac{k}{2} h ; \quad k=2 \lambda_{h} / h \tau
$$

For $y=H$ :

$$
\begin{aligned}
v_{H}=-\lambda_{H} / \tau & =-\frac{k}{2}(2 H-h)=-\lambda_{h}(2 H-h), h \tau, \\
\lambda_{h} & =\frac{h}{2 H-h} \lambda_{H} .
\end{aligned}
$$

Inserting Equations (8) and (9) into Equation (7) gives

$$
v_{y}= \begin{cases}-\frac{\lambda_{h}}{h^{2} \tau} y^{2}=-\frac{\lambda_{H}}{h(2 H-h) \tau} y^{2}, & 0 \leqslant y \leqslant h \\ -\frac{(2 y-h) \lambda_{h}}{h \tau}=-\frac{2 y-h}{2 H-h} \frac{\lambda_{H}}{\tau}, & h \leqslant y \leqslant H,\end{cases}
$$

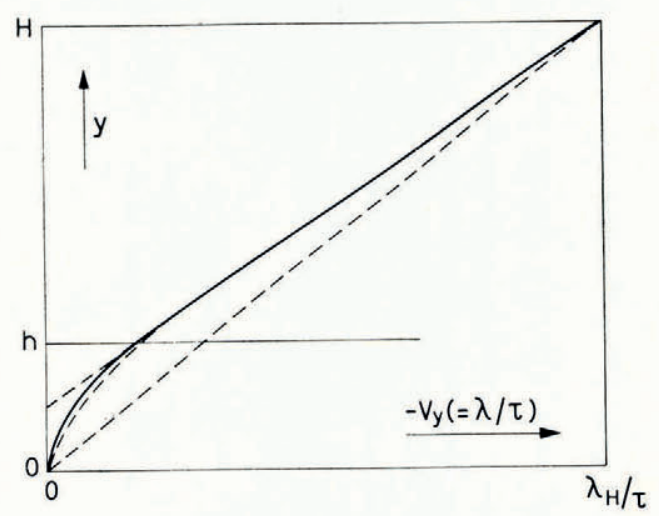

Fig. 3. Vertical velocity $v_{y}$ as a function of the distance $y$ from the bottom. Dashed line: the Nye flow model; full curve: the flow model described on p. 217 . The dashed curve close to the full curve corresponds to the horizontal velocity profile calculated by Weertman $(1968)$; $c$. Fig. 2. 
which is shown in Figure 3 (cf. discussion on p. 21 7-18). The straight line in the upper range intersects the $y$-axis at $y=h / 2$. Consequently, in the same range, $h \leqslant y \leqslant H$, we can use Nye's model and Equations (I), (2) and (3), if $H$ and $y$ are replaced by $H-\frac{h}{2}$ and $y-\frac{h}{2}$

$$
\begin{gathered}
\lambda=\frac{2 y-h}{2 H-h} \lambda_{H}=(2 y-h) \frac{\lambda_{h}}{h}, \\
\lambda=\lambda_{H} \exp \left[-\frac{2 \lambda_{H}}{(2 H-h) \tau} t\right]=\lambda_{H} \exp \left(-\frac{\lambda_{h}}{h \tau} t\right), \\
t=-\frac{(2 H-h) \tau}{2 \lambda_{H}} \ln \frac{2 y-h}{2 H-h}=-\frac{h \tau}{2 \lambda_{h}} \ln \frac{2 y-h}{2 H-h}, \quad h \leqslant y \leqslant H .
\end{gathered}
$$

In the range $0 \leqslant y \leqslant h$, Equation ( 10 ) gives

$$
v_{y} \equiv \frac{\mathrm{d} y}{\mathrm{~d} t}=-\frac{\lambda}{\tau}=-\frac{\lambda_{h}}{h^{2} \tau} y^{2} .
$$

Integration over the intervals $h \rightarrow y$ and $t_{h} \rightarrow t\left(t_{h}\right.$ being the age of ice at $y=h$ given by Equation (12)) leads to

or

$$
\begin{aligned}
y & =\frac{h}{\mathrm{I}+\lambda_{h}\left(t-t_{h}\right) / h \tau} \\
t-t_{h}=\frac{h^{2} \tau}{\lambda_{h}}\left(\frac{\mathrm{I}}{y}-\frac{\mathrm{I}}{h}\right) & =\frac{(2 H-h) \tau}{\lambda_{H}}\left(\frac{h}{y}-\mathrm{I}\right), \quad 0 \leqslant y \leqslant h
\end{aligned}
$$

and from Equations (13) and (14)

$$
\lambda=\lambda_{h}\left[\mathrm{I}+\lambda_{h}\left(t-t_{h}\right) / h \tau\right]^{-2} .
$$

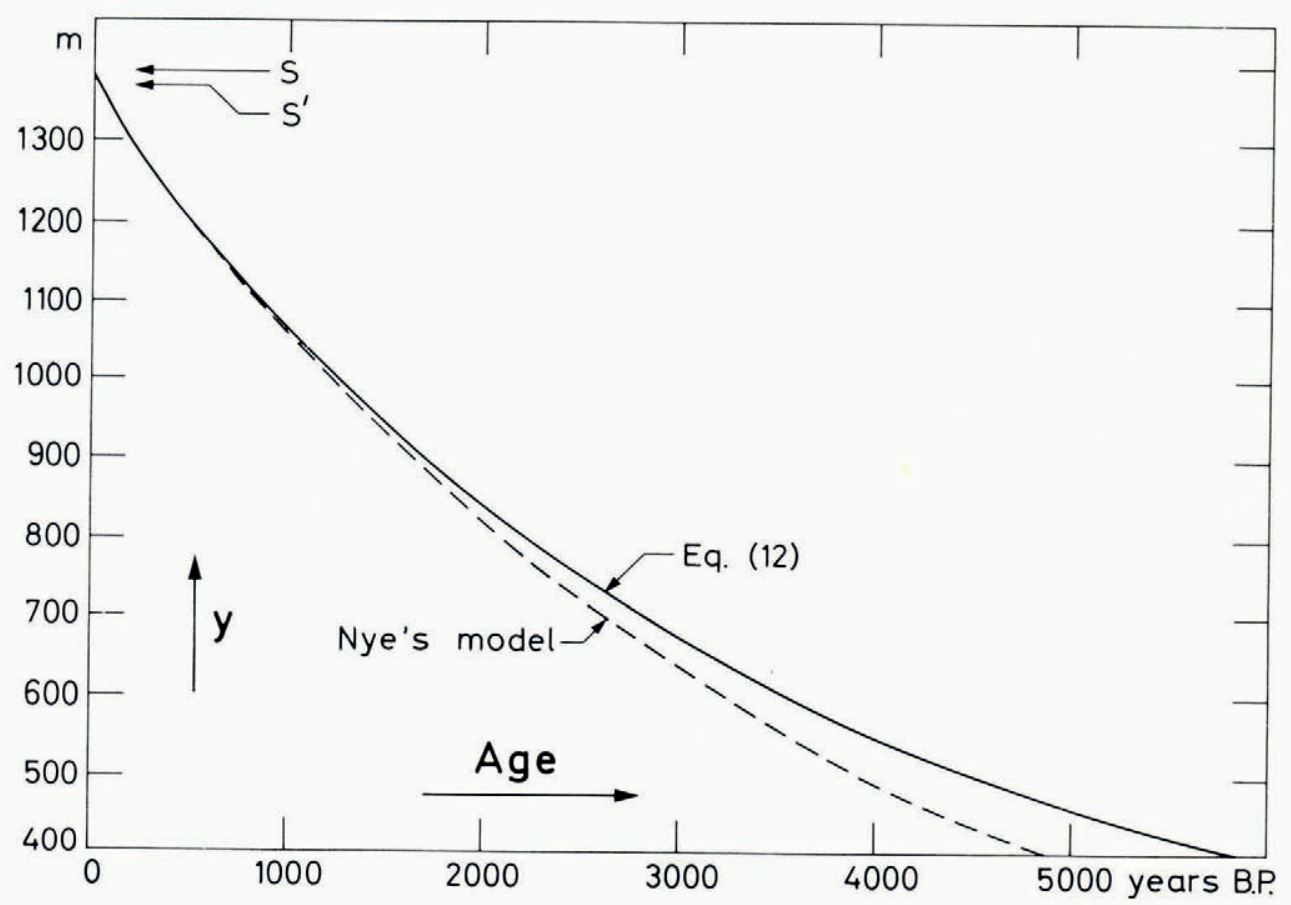

Fig. 4. Age of the ice in the Camp Century core as a function of the distance y from the bottom, $y \geqslant h$. $S$ is the Ig66 surface $(y=I 387.5 \mathrm{~m})$ and $S^{\prime}$ is the 1966 surface corrected for low densities in the upper layers $\left(y^{\prime}=H=1367.5 \mathrm{~m}\right.$ of ice $)$. 
Using the equations way back in time implies that $H$ and $\lambda_{H}$ are independent of $x$ and, furthermore, steady-state conditions in a broad sense, i.e. $H, \lambda_{H}$ and ice temperature $T$ are constant in time.

The former assumption seems justified (i) by the direction of the movement at Camp Century being approximately parallel to the iso-accumulation curves in the area (Mock, I 968), and (ii) by the site of formation of even a 15 ooo year old section of the core being barely more than $50 \mathrm{~km}$ from Camp Century (the surface velocity is $3.3 \mathrm{~m} /$ year (Mock, referred to by Weertman (I968)). As to the changes in the non-independent parameters, $H, \lambda_{H}$ and $T$, many thousand years back in time, it might be reasonable to assume lower $\lambda_{H}$ and $T$, but higher $H$ during the glaciation. Lower $\lambda_{H}$ in that period would correspond to a closer packing of the annual layers, which, on the other hand, would be counteracted by slower thinning of the layers due to lower temperature (i.e. higher viscosity of the ice) and higher $H$. However, we have no means of verifying such assumptions, so all that we can do at present is to calculate the time scale by using the present constants and try, by other means, to check if and when an error enters (these remarks, of course, should also be considered in connection with the thinning of the layers (Fig. 3)).

The mean value of $\lambda_{H}$ over the last $\mathrm{r}$ oo years has been $0.35 \pm 0.03 \mathrm{~m}$ of ice, as shown by Crozaz and Langway ( 1966 ) by the ${ }^{210} \mathrm{~Pb}$ method. The surface to bottom distance, $H$, was measured as $1387.5 \mathrm{~m}$ in 1966 (Hansen and Langway, I966), corresponding to $1367.5 \mathrm{~m}$

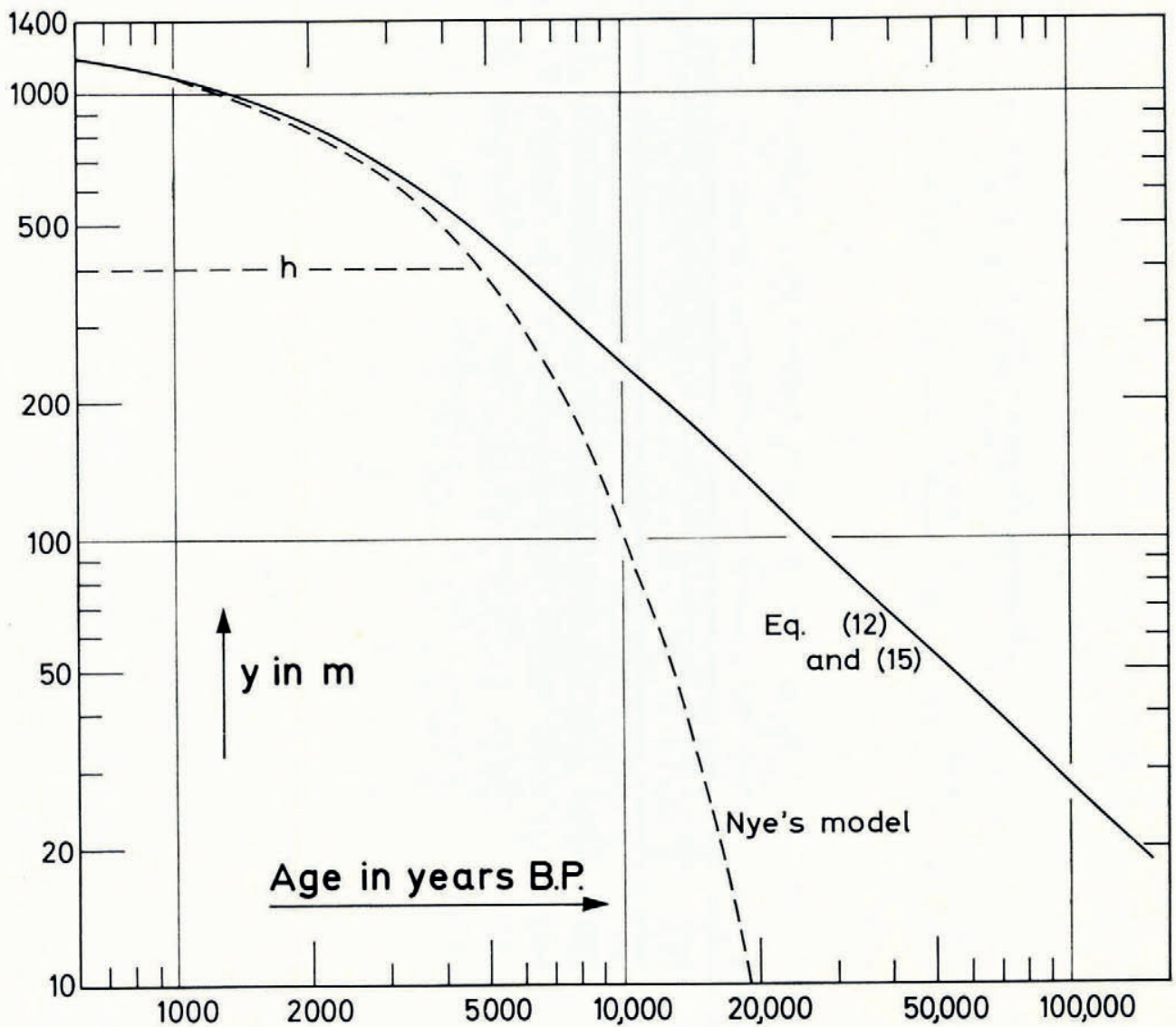

Fig. 5. Age of the ice in the Camp Century core as a function of the distance y from the bottom (I I $60 \mathrm{~m} \geqslant y \geqslant 20 \mathrm{~m})$, both on a logarithmic scale. 
of ice in view of the low densities in the upper layers (personal communication from C. C. Langway, Jr.).

Thus, we can use Equations (I2) and (I5) with $H=\mathrm{I} 367.5 \mathrm{~m}, h=400 \mathrm{~m}, \lambda_{H}=0.35 \mathrm{~m}$, and $\tau=$ I year. For $t>6000$ years, we can write

$$
t=\left(\frac{2.670 \times \mathrm{IO}^{6}}{y}\right)-800 \text { years B.P. }
$$

The result is shown by the full curves in Figures 4 and 5. According to the Nye model (dashed curve; Equation (4)), only the lowest few metres of ice should be more than 20 ooo years old, whereas in our model the ice reaches this age $\mathrm{I} 30 \mathrm{~m}$ above the bottom.

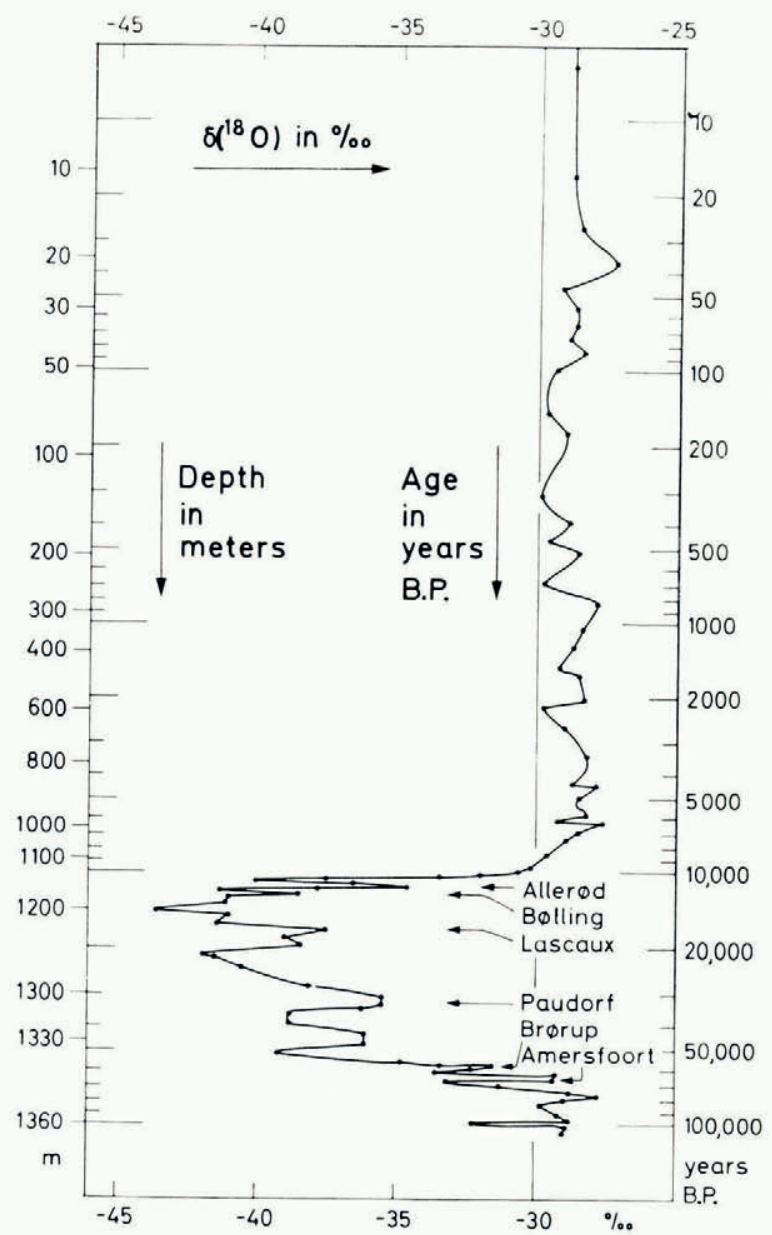

Fig. 6. The heavy oxygen isotope concentration, $\delta\left({ }^{8} \mathrm{O}\right)$, of sections of the Camp Century core versus the age of the ice (Equations

(12) and (I5)) plotted on a logarithmic scale to the right. The outer scale to the left gives the corresponding depth below the 1966 surface. The isotope data are given as relative deviation of the ${ }^{18} \mathrm{O} /{ }^{16} \mathrm{O}$ ratio from that of standard mean ocean water. (From Dansgaard and others, unpublished.)

\section{Experimental Evidence}

The validity of the flow model described above has been checked in two independent ways. First, the flow model was used as a basis for calculating the temperature profile down the bore hole (Dansgaard and Johnsen, 1969). The result fitted the profile measured by 
Hansen and Langway ( 1966 ) within $\pm 0.6^{\circ} \mathrm{C}$. The calculated temperature difference between surface and bottom deviated only $0.3^{\circ} \mathrm{C}$ from the measured difference. Using the Nye model, Weertman (ig68) found a deviation of $2.7^{\circ} \mathrm{C}$.

Secondly, when stable oxygen-isotope data for about i 600 samples from the core were plotted against the age of the ice in our time scale (Fig. 6), they showed a variation which was in complete agreement with practically all known climatic changes within the last 70000 or I 00 ooo years (for further details, cf. Dansgaard and others, in press). The geochemical explanation for this is the fact that the isotopic composition of precipitation at high latitudes is mainly determined by the temperature of formation (Dansgaard, I954, I964; Gonfiantini and Picciotto, 1959), which causes seasonal isotopic oscillations in the ice strata, as well as longperiod isotopic variations in phase with climatic changes.

The agreement with other quite independent climatological estimates, covering nearly I 00 ooo years, leads us to the conclusion that the time scale and therefore our flow model is basically correct down to 30 or $35 \mathrm{~m}$ above the bottom. Below that level, the flow pattern is probably influenced by the irregular topography of the bottom, which is also indicated by visual observation of the lowest silty core sections.

Moreover, unless the influences of the various parameters, which determine the flow pattern, quite accidentally counterbalance each other (e.g. as outlined on p. 220), it would seem as if $\lambda_{H}$ and $H$ have not deviated considerably from their present values in the Camp Century area.

One might ask how the time scale is influenced by the choice of $h$ (cf. Fig. 2). To check this, we consider a horizon $y=209.0 \mathrm{~m}$ above the bottom. In our time scale $(h=400 \mathrm{~m})$ the age is $t_{209}=\mathrm{I} 2$ ooo years with an uncertainty of barely more than $\mathrm{I} \%$, whereas, for $h=300 \mathrm{~m}(500 \mathrm{~m}), t_{209}$ would be 10400 years B.P. (1 3600 years B.P.). Thus, if $f(y)$ is accepted in accordance with Equation (6), $h$ must be very close to $400 \mathrm{~m}$.

\section{Acknowledgement}

The authors are indebted to the Carlsberg Foundation, Copenhagen, for financial support.

MS. received I5 December 1968

\section{REFERENCES}

Aegerter, S., and others. I969. Studies based on the tritium content of ice samples, by S. Aegerter, H. Oeschger, A. Renaud and E. Schumacher. Meddelelser om Gronland, Bd. 177, Nr. 2, p. 76-92.

Crozaz, G., and Langway, C. C., jr. 1966 . Dating Greenland firn-ice cores with $\mathrm{Pb}^{2 \mathrm{10}}$. Earth and Planetary Science

Letters, Vol. I, No. 4, p. I $94-96$.
Crozaz, G., and others. 1964 . Antarctic snow chronology with $\mathrm{Pb}^{210}$, by G. Crozaz, E. [E.] Picciotto and W. de Breuck. Journal of Geophysical Research, Vol. 69, No. 12, p. 2597-604.

Dansgaard, W. 1954. The Or8-abundance in fresh water. Geochimica et Cosmoshimica Acta, Vol. 6, Nos. 5-6,

p. 241-6o.
Dansgaard, W. 1964. Stable isotopes in precipitation. Tellus, Vol. 16, No. 4, p. 436-68.

Dansgaard, W., and Johnsen, S. J. 1969 . Comment on paper by J. Weertman, "Comparison between measured and theoretical temperature profiles of the Camp Century, Greenland, borehole". Fournal of Geophysical Research, Vol. 74, No. 4, p. 1 1 o9-10. [See also "Errata", Journal of Geophysical Research, Vol. 74.]

Dansgaard, W., and others. 1966 . The $\mathrm{Si}^{32}$ fallout in Scandinavia; a new method for ice dating, by W. Dansgaard, H. B. Clausen and A. Aarkrog. Tellus, Vol. 18, Nos. 2-3, p. 187-91.

Dansgaard, W., and others. In press. One thousand centuries of climatic record from Camp Century, by W.

Dansgaard, S. J. Johnsen, J. Moller and C. C. Langway, Jr. Science.
Dansgaard, W., and others. Unpublished. Oxygen isotope analysis of a core representing a complete vertical profile of a polar ice sheet, by W. Dansgaard, S. J. Johnsen, J. Møller and C. C. Langway, Jr. [Paper read at International Symposium on Antarctic Glaciological Exploration, Hanover, N.H., U.S.A., 3-7 September

I968.]
Epstein, S., and Sharp, R. P. 1959. Oxygen isotope studies. Transactions. American Geophysical Union, Vol. 40, No. 1, p. $81-84$.

* Because, in the same range, the late interstadials (Allerød and Bølling) are reflected by the stable-isotope curve in time intervals (in our time scale) only 100 years from the ${ }^{14} \mathrm{C}$ dates (II $800-1$ I 000 years B.P. and I $2400-$ 12 ooo years B.P.). 
Goldberg, E. D. I963. Geochronology with lead-2 Io. (In Radioactive dating. Proceedings of the symposium on radioactive dating held by the International Atomic Energy Agency in co-operation with the foint Commission on Applied Radioactivity (ICSU) in Athens, 19-23 November 1962. Vienna, International Atomic Energy Agency, p. 12 1-31.)

Gonfiantini, R., and Picciotto, E. E. 1959. Oxygen isotope variations in Antarctic snow samples. Nature, Vol. 184 , No. 4698 , p. $1557^{-5} 8$

Haefeli, R. 196r. Contribution to the movement and the form of ice sheets in the Arctic and Antarctic. Journal of Glaciology, Vol. 3, No. 3o, p. I 1 33-51.

Hansen, B. L., and Langway, C. C., jr. 1966. Deep core drilling in ice and core analysis at Camp Century, Greenland, 1961-1966. Antarctic Fournal of the United States, Vol. I, No. 5, p. 207-08.

Johnsen, S. J., and Dansgaard, W. Unpublished. Obliteration of stable isotope oscillations in snow and ice. [In preparation, I 969 .]

Johnsen, S. J., and others. Unpublished. Comparison between visual and isotopic stratigraphy of the Camp Century ice core, by S. J. Johnsen, W. Dansgaard and C. C. Langway, Jr. [In preparation, 1969.]

Langway, C. C., jr. 1967. Stratigraphic analysis of a deep ice core from Greenland. U.S. Cold Regions Research and Engineering Laboratory. Research Reprort 77.

Mock, S. J. r 968 . Snow accumulation studies on the Thule peninsula, Greenland. Fournal of Glaciology, Vol. 7 . No. 49 , p. $59^{-76}$.

Nye, J. F. 1951. The flow of glaciers and ice-sheets as a problem in plasticity. Proceedings of the Royal Society, Ser. A, Vol. 207, No. 1091, p. 554-72.

Nye, J. F. 1957. The distribution of stress and velocity in glaciers and ice-sheets. Proceedings of the Royal Society, Ser. A, Vol. 239, No. 1216, p. $113-33$.

Nye, J. F. 1959. The motion of ice sheets and glaciers. Journal of Glaciology, Vol. 3, No. 26, p. $493-507$.

Nye, J. F. ${ }^{1} 963$. Correction factor for accumulation measured by the thickness of the annual layers in an ice sheet. Journal of Glaciology, Vol. 4, No. 36, p. 785-88.

Oeschger, H., and others. 1967. Instruments and methods. An in situ gas-extraction system to radiocarbon date glacier ice, by H. Oeschger, B. Alder and C. C. Langway, Jr. Journal of Glaciology, Vol. 6, No. 48, p. 939-42.

Scholander, P. F., and others. 1962. Radio-carbon age and oxygen-1 8 content of Greenland icebergs, by P. F. Scholander, W. Dansgaard, D. C. Nutt, H. deVries, L. K. Coachman and E. Hemmingsen. Meddelelser om Gronland, Bd. 165, Nr. I.

Weertman, J. 1968. Comparison between measured and theoretical temperature profiles of the Camp Century. Greenland, borehole. Journal of Geophysical Research. Vol. 73, No. 8, p. 2691-700. 